\title{
NIVELACIJSKI PLAN KRUŽNIH RASKRIŽJA KAO SADRŽAJ PROJEKATA JAVNIH CESTA ${ }^{4}$
}

\begin{abstract}
SAŽETAK
U radu se daje analiza i usporedba visinskog vođenja klasičnih raskrižja u jednoj razini i kružnih raskrižja te se detektira problem neusklađenosti regulative koja propisuje obavezan sadržaj projekata za javne ceste koji se odnosi na raskrižja. Također se daju neki primjeri načina grafičkog prikaza kružnog raskrižja kao dijela sadržaja projekata za javne ceste te potrebnih točaka iskolčenja kružnih raskrižja. Kako su se u Hrvatskoj donedavno na mjestima križanja prometnih tokova dominantno primjenjivala klasična raskrižja u jednoj razini, tako su i kod sudionika u gradnji ostali neki zahtjevi koji su neprimjenjivi za kružna raskrižja i kod zadavanja projektnih zadataka i kod izrade nacrta kojim bi se obradilo visinsko vođenje kružnog raskrižja. Kružna raskrižja imaju različitu geometriju te su zbog toga i različiti ulazni podatci koji su potrebni za računalne programe za projektiranje prometnica od onih za projektiranje klasičnog raskrižja u jednoj razini. Surha izrade članka je ukazati na aktualna pitanja i probleme kod projektiranja kružnih raskrižja, dok je cilj rada preporuka sadržaja koji projekt javne ceste mora imati u slučaju projektiranja kružnog raskrižja.
\end{abstract}

Ključne riječi: kružna raskrižja, nivelacijski plan, niveleta, visinsko vođenje

\section{UVOD}

Posljednjih dvadeset godina svjedoci smo naglog povećanja izgradnje kružnih raskrižja kao elementa cestovne mreže na mjestima gdje se križaju prometni tokovi cesta i ulica. Iz tog razloga zbog višegodišnjeg nedostatka domaćih propisa i standarda za projektiranje kružnih raskrižja poduzeće „Hrvatske ceste d. o. o." je u srpnju 2014. izdalo „Smjernice za projektiranje kružnih raskrižja na državnim cestama" koje je izradio Građevinski fakultet Sveučilišta u Rijeci. Jednako tako, kroz praksu su uočene nejasnoće kod zahtjeva grafičkog prikaza samih kružnih raskrižja kod većine sudionika u gradnji. Kako su se donedavno na mjestima križanja prometnih tokova dominantno primjenjivala klasična raskrižja u jednoj razini, tako su i kod investitora ostali neki zahtjevi kod zadavanja projektnih zadataka koji su neprimjenjivi za kružna raskrižja. Konkretno, u projektnim zadatcima ili zahtjevima investitora moguće je naići na zahtjev za nacrt uzdužnog profila kroz sam kružni prometni trak, što s aspekta samog projektiranja nije opravdano. Kako kod projektiranja kružnog raskrižja vrijede različita pravila i ulazni podatci potrebni kod računalnih programa za

\footnotetext{
Mag. ing. aedif., asistent, Veleučilište u Rijeci, Vukovarska 58, 51000 Rijeka, Hrvatska.E-mail: veljko.pevalek@veleri.hr Dr. sc., prof. v. š., Veleučilište u Rijeci, Vukovarska 58, 51000 Rijeka, Hrvatska.E-mail: ivica.barisic@veleri.hr

3 Struč. spec. ing. traff., asistent, Veleučilište u Rijeci, Vukovarska 58, 51000 Rijeka, Hrvatska. E-mail: damir.pilepic@veleri.hr

4 Datum primitka rada: 15. 1. 2018.; datum prihvaćanja rada: 1. 3. 2018.
} 
projektiranje prometnica od onih za projektiranje klasičnog raskrižja u jednoj razini, tako su nam i kod visinskog definiranja geometrije kružnih raskrižja potrebni i drugačiji grafički nacrti. Na taj način dolazi do nedoumice kod projektanata prilikom izrade projekata kružnih raskrižja čije nacrte je potrebno izraditi, a tako i kod samih izvođača prilikom prenošenja podataka iz projekata na teren i nadzornog inženjera kod provođenja stručnog nadzora.

U ovom se radu daju neki primjeri nivelacijskog plana kao grafičkog prikaza kružnog raskrižja u sklopu sadržaja projekata za javne ceste te potrebnih točaka iskolčenja kružnih raskrižja Primjeri su izrađeni na programskom paketu za trodimenzionalno građevinsko projektiranje AutoCAD Civil3d.

Cilj ovoga rada je ukazati na aktualna pitanja i probleme kod projektiranja kružnih raskrižja te sugerirati moguće izmjene u sadržaju dokumentacije koje bi pridonijele kvaliteti dokumentacije te time i cjelokupnog postupka projektiranja i izvedbe kružnih raskrižja.

\section{ELEMENTI VISINSKOG VOĐENJA KOD RASKRIŽJA U JEDNOJ RAZINI}

Čvorišta (raskrižja) su točke u cestovnoj mreži na kojima se povezivanjem dviju ili više cesta križaju, isprepliću, spajaju ili razdvajaju prometni tokovi.

$\mathrm{Na}$ čvorištima cesta i ulica uslijed prometnih radnji koje nisu svojstvene otvorenim dijelovima trase, naročito su naglašeni problemi propusnosti i sigurnosti prometa (Korlaet, 1995).

\section{1 Visinsko vođenje ceste}

Uzdužni profil je prilog (nacrt) s prikazom nivelete ceste i terena u pravokutnom koordinatnom sustavu, sa stacionažama na apscisnoj osi i nadmorskim visinama kota nivelete na ordinati.

Niveleta je prostorna krivulja kojom se definiraju visinski odnosi ceste. Nastaje presjekom plohe kolnika i vertikalne plohe položene po osi ceste ili paralelno s njom (Legac, 2006).

Kod promjene nagiba nivelete lomovi se zaobljuju vertikalnim kružnim lukovima. Lom nivelete može biti konveksan (hrbat) ili konkavan (uvala) (Korlaet,1995).

Slika 1. Uzdužni profil s niveletom ceste

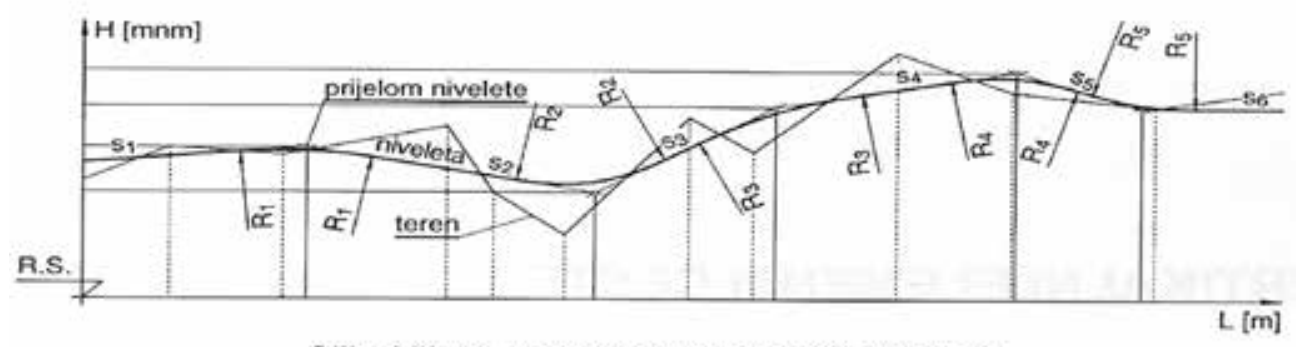

Slika VII-01. Uzdužni profil s niveletom ceste

Izvor: Legac, 2006 
Osim uzdužnog profila kao grafički prilog visinskog vođenja moraju se izraditi i poprečni profili. Poprečni profili jesu vertikalni presjeci koji se postavljaju na željenu udaljenost (ovisno o razini projekta i terenskim uvjetima) duž osi ceste. Oni se izrađuju nakon što je niveleta odnosno uzdužni profil potpuno definiran. Poprečni presjeci prikazuju položaj i iznose svih elemenata po širini presjeka te njihov odnos prema okolnom terenu. U poprečnim profilima kao element visinskog vođenja kolnika osim kote nivelete vide se i kote rubova prometnice koji se određuju putem poprečnih nagiba i širine kolničkih traka prometnice.

Slika 2. Poprečni profil

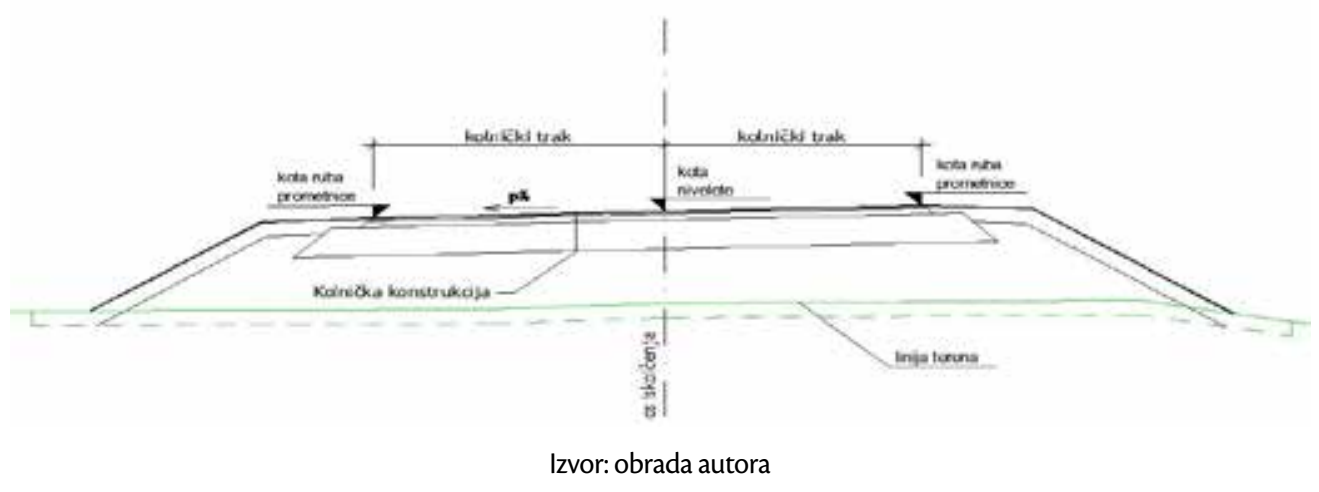

\subsection{Klasična raskrižja u jednoj razini}

Kod klasičnih raskrižja u jednoj razini kao grafički prilozi visinskog vođenja trase ovisno o broju cesta koje se križaju izrađuje se onoliko uzdužnih profila koliko ima prometnica koje se križaju. Prilikom izrade uzdužnog profila kod uređenja nivelete koja se polaže po vertikali iznad tlocrtne osi ceste unose se pravci pod određenim uzdužnim nagibom između kojih se prema potrebi ubacuju konkavni ili konveksni kružni lukovi propisanih polumjera. Kada je niveleta definirana određuju se poprečni nagibi prometnice na osnovi kojih se dobiju visine rubova prometnice. Poprečni nagib glavnog pravca mjerodavan je za utvrđivanje uzdužnog nagiba sporednog pravca u području raskrižja.

Na slici 3. i 4. prikazane su sheme klasičnog četverokrakog raskrižja koje se sastoji od dvije prometnice: glavne i sporedne ceste. 
Slika 3. Prilagođavanje uzdužnog nagiba na glavnom ceste u zoni raskrižja

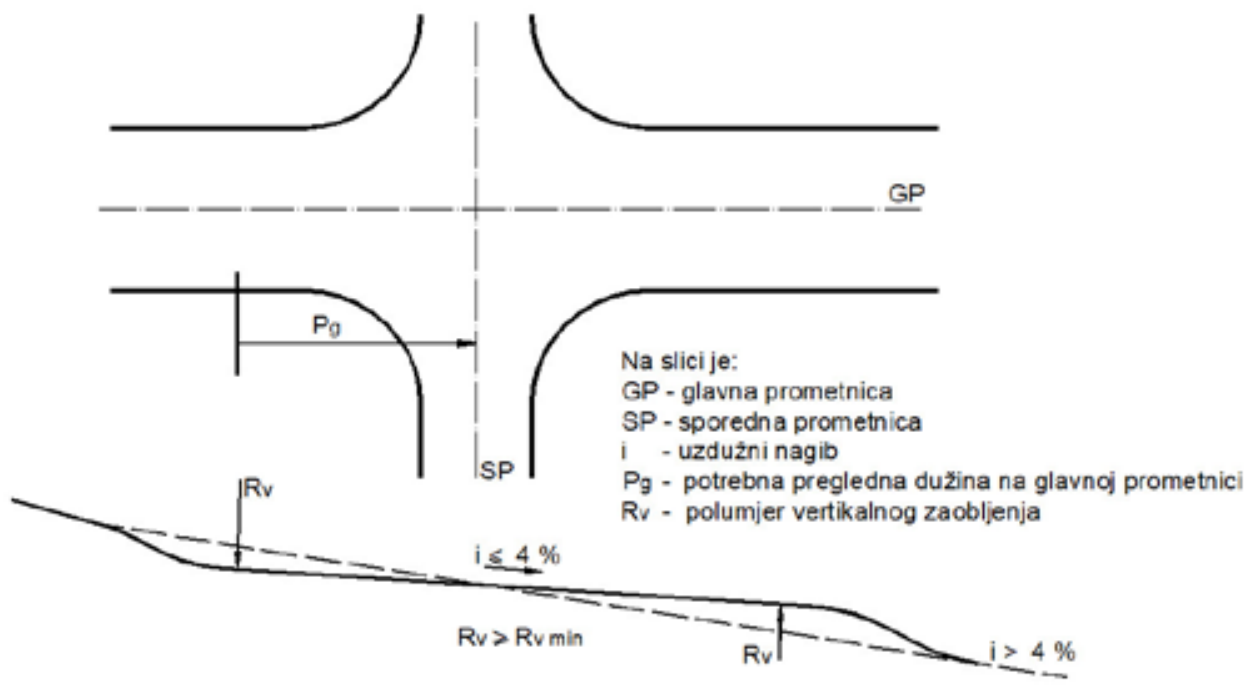

Izvor: HRN U.C4.050

Slika 4. Prilagođavanje uzdužnog nagiba sporedne ceste u zoni raskrižja

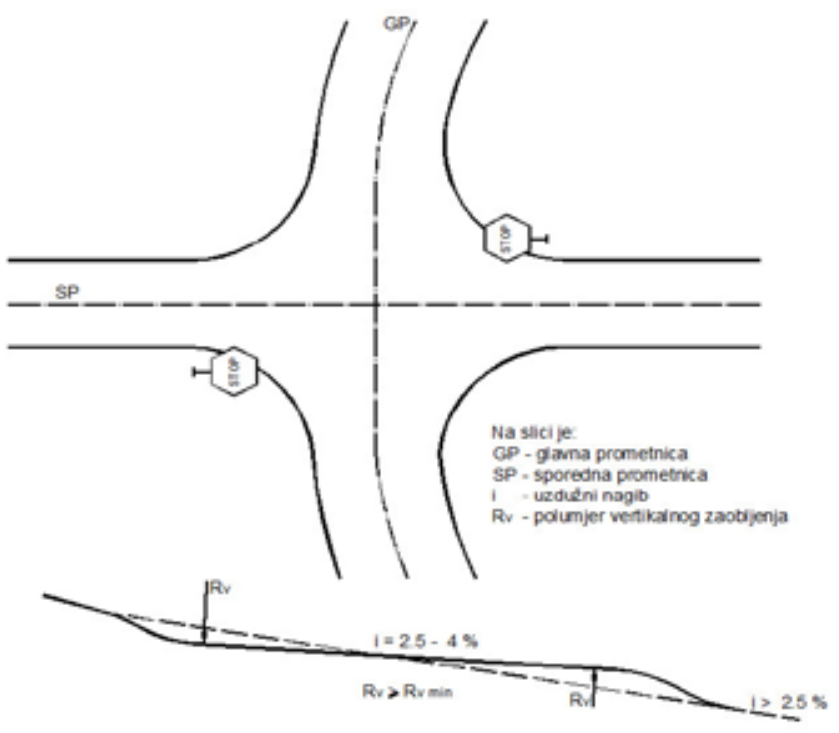

Izvor: HRN U.C4.050 


\subsection{Kružna raskrižja}

Kružno raskrižje je kanalizirano raskrižje kružnog oblika s neprovoznim, djelomično ili u cijelosti povoznim/provoznim središnjim otokom i kružnim voznim trakom na koji se vežu tri ili više priključnih cesta u razini i u kojem se promet odvija u smjeru suprotnom kretanju kazaljke na satu (Smjernice za projektiranje kružnih raskrižja na državnim cestama, 2011).

Slika 5. Osnovni elementi kružnog raskrižja

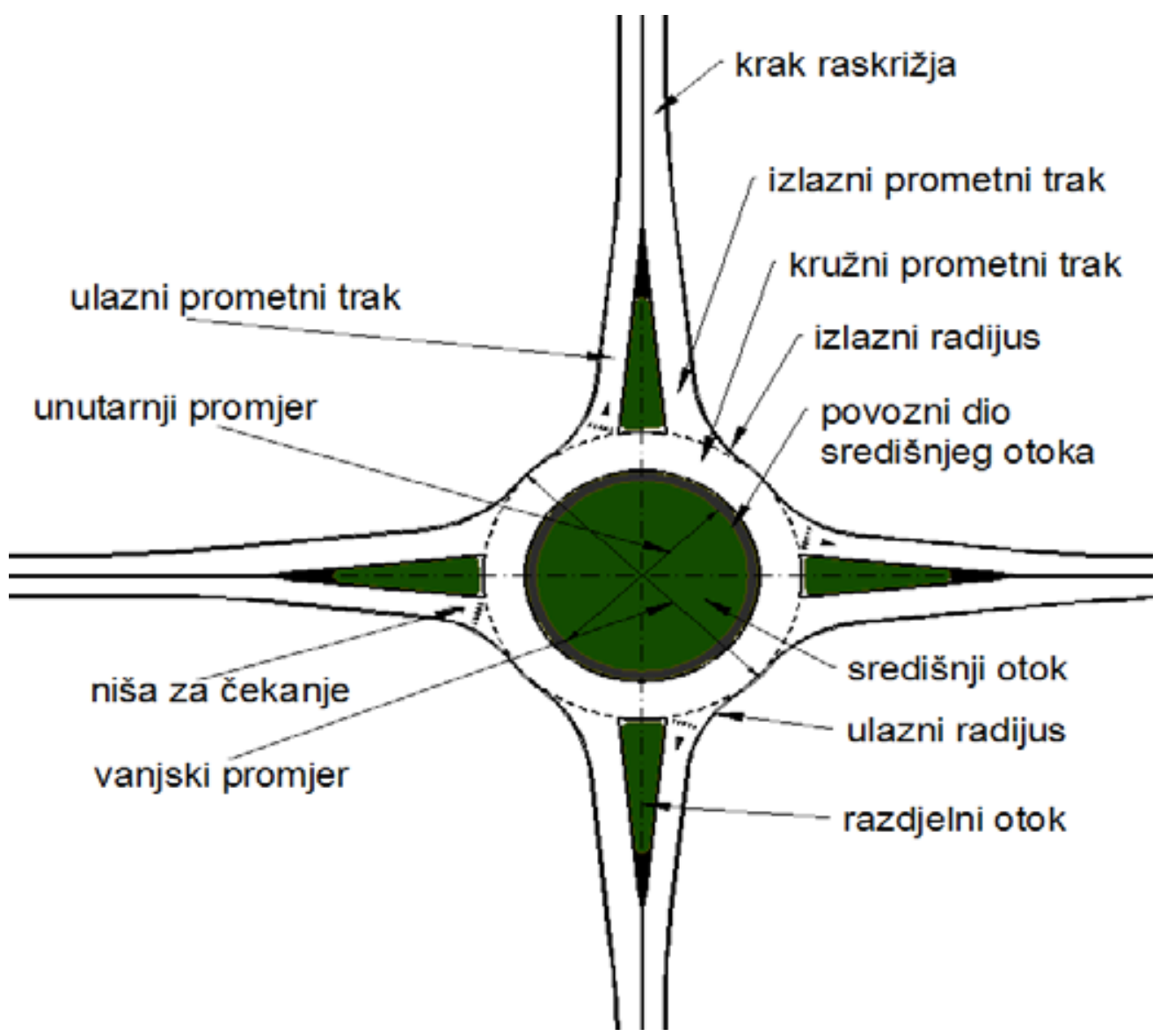

Izvor: Smjernice za projektiranje kružnih raskrižja na državnim cestama, 2011

\subsubsection{Visinsko vođenje trase privoza kružnog raskrižja}

Kod visinskog vođenja trase privoza (krakova) kružnog raskrižja vrijede isti načini izrade grafičkih priloga kao i za otvorenu trasu ceste odnosno klasična raskrižja. Izradi se onoliki broj uzdužnih profila koliko ima privoza, a sve prema smjernicama za projektiranje kružnih raskrižja na osnovi kojih se definiraju i visine rubova kolnika samih privoza. 
Slika 6. (uzdužni profil) vanjskog ruba kružnog kolnika u ravnini pod nagibom

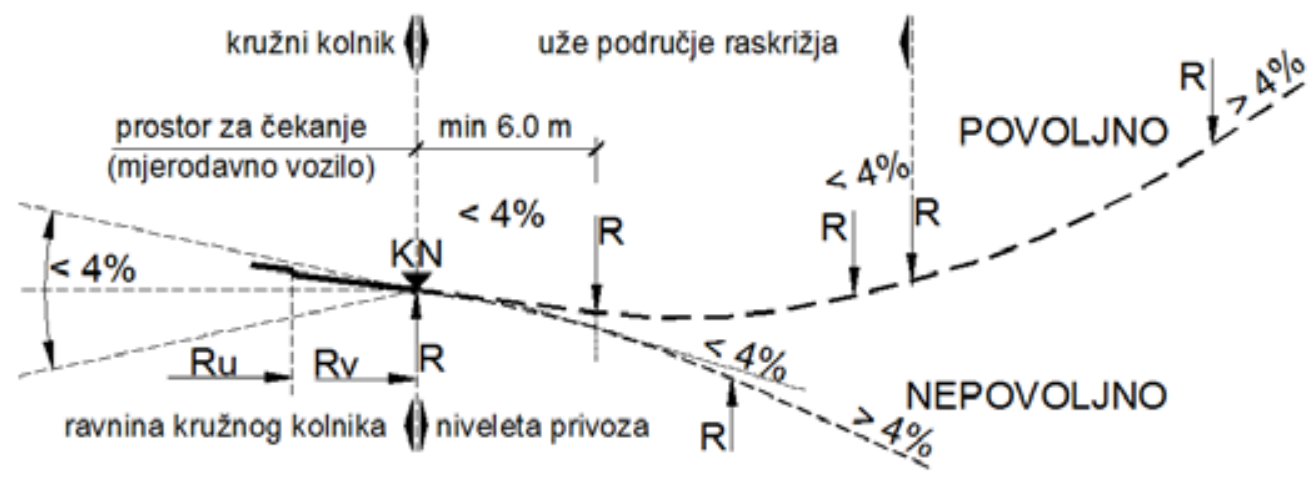

Izvor: Smjernice za projektiranje kružnih raskrižja na državnim cestama, 2011

Niveletu privoza treba uklopiti u kotu vanjskog ruba kružnog kolnika, a poželjno je prihvatiti i poprečni nagib kružnog kolnika kao početnu/završnu tangentu nivelete privoza.

\subsubsection{Visinsko vođenje kružnog kolnika}

Kružni kolnik raskrižja visinski je određen položajem vanjskog ruba kolnika. U pravilu se vanjski rub kolnika nalazi u ravnini, čime se definira i niveleta vanjskog ruba kružnog kolnika.

Polaganje nivelete vanjskog ruba kolnika na neki drugi način kolnika nije primjereno malim i srednjim kružnim raskrižjima. Odstupanja su prihvatljiva kod preoblikovanja postojećih u kružna raskrižja.

Povoljna je izvedba vanjskog ruba kolnika u horizontalnoj ravnini. Ako je opravdana izvedba u nagibu, tada nagib ravnine vanjskog ruba kolnika treba biti do 2,50\%, a izuzetno do $4 \%$ kod preoblikovanja postojećih u kružna raskrižja. U takvim slučajevima posebnu pozornost treba posvetiti odvodnji površinskih oborinskih voda i stabilnosti teretnih vozila i autobusa (Smjernice za projektiranje kružnih raskrižja na državnim cestama, 2011). 
Slika 7. Nivelacijski plan kružnog kolnika: a - horizontalan teren; b - teren u nagibu < 2,5\%; c-teren u nagibu $>2,5 \%$

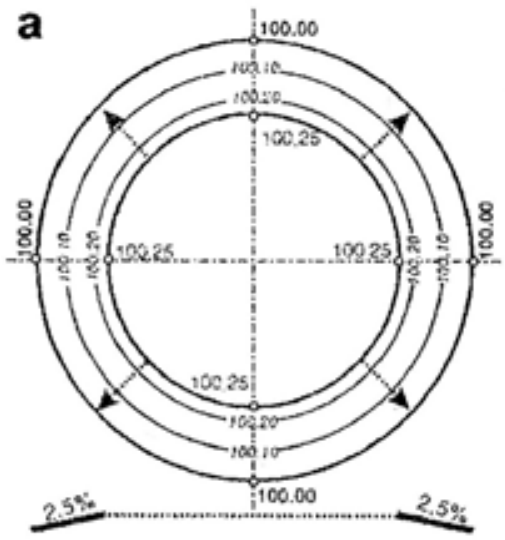

b
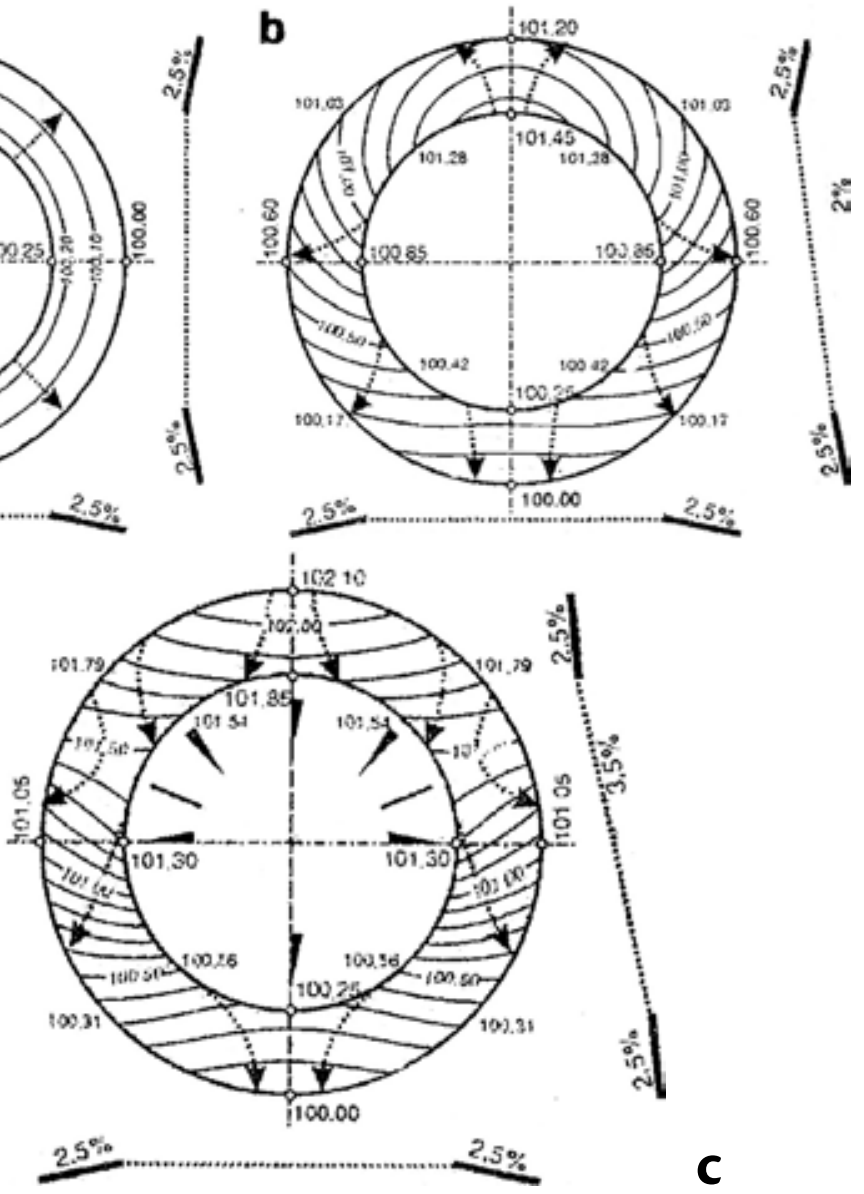

C

Izvor: Maletin, 2009

Kod samog visinskog vođenja i određivanja visinskih elemenata kružnog kolnika ne može se više ponoviti isti postupak kao što smo imali kod otvorene dionice ceste odnosno kod visinskog vođenja trase klasičnog raskrižja u razini.

Kad je ravnina u kojoj leži vanjski rub kružnog kolnika horizontalna, postupak visinskog vođenja vrlo je jednostavan; sve točke vanjskog ruba leže na istoj nadmorskoj visini. Putem širine i poprečnog nagiba kružnog kolnika koji nam služi zbog odvodnje dobijemo visinu unutarnjeg ruba kružnog kolnika. Također sve točke unutarnjeg ruba moraju ležati na istoj nadmorskoj visini. Kao što je u ovom slučaju bilo jednostavno visinsko oblikovanje jednako je jednostavno i prenošenje točaka iskolčenja na teren i praćenje izgradnje.

Kad je ravnina u kojoj leži vanjski rub kružnog kolnika pod određenim nagibom, situacija je nešto složenija. Naime, vanjski rub kolnika kružnog raskrižja koji je mjerodavan za određivanje visinskih 
elemenata raskrižja u tlocrtu (situaciji) je kružnica. Ako se uzme da je vanjski rub kružnog kolnika ujedno i os, dobije se niveleta vanjskog ruba kolnika koja je krivulja koja se ponaša prema sljedećoj trigonometrijskoj funkciji:

$$
f(x)=S_{y}+R_{v} \sin x \operatorname{tg} \phi
$$

gdje je $S_{y}$ nadmorska visina središta kružnog raskrižja, $R_{v}$ polumjer vanjskog ruba kružnog kolnika a $\phi$ kut nagiba ravnine u kojoj leži vanjski rub kružnog kolnika.

Slika 8. Graf (niveleta) vanjskog ruba kružnog kolnika u ravnini pod nagibom
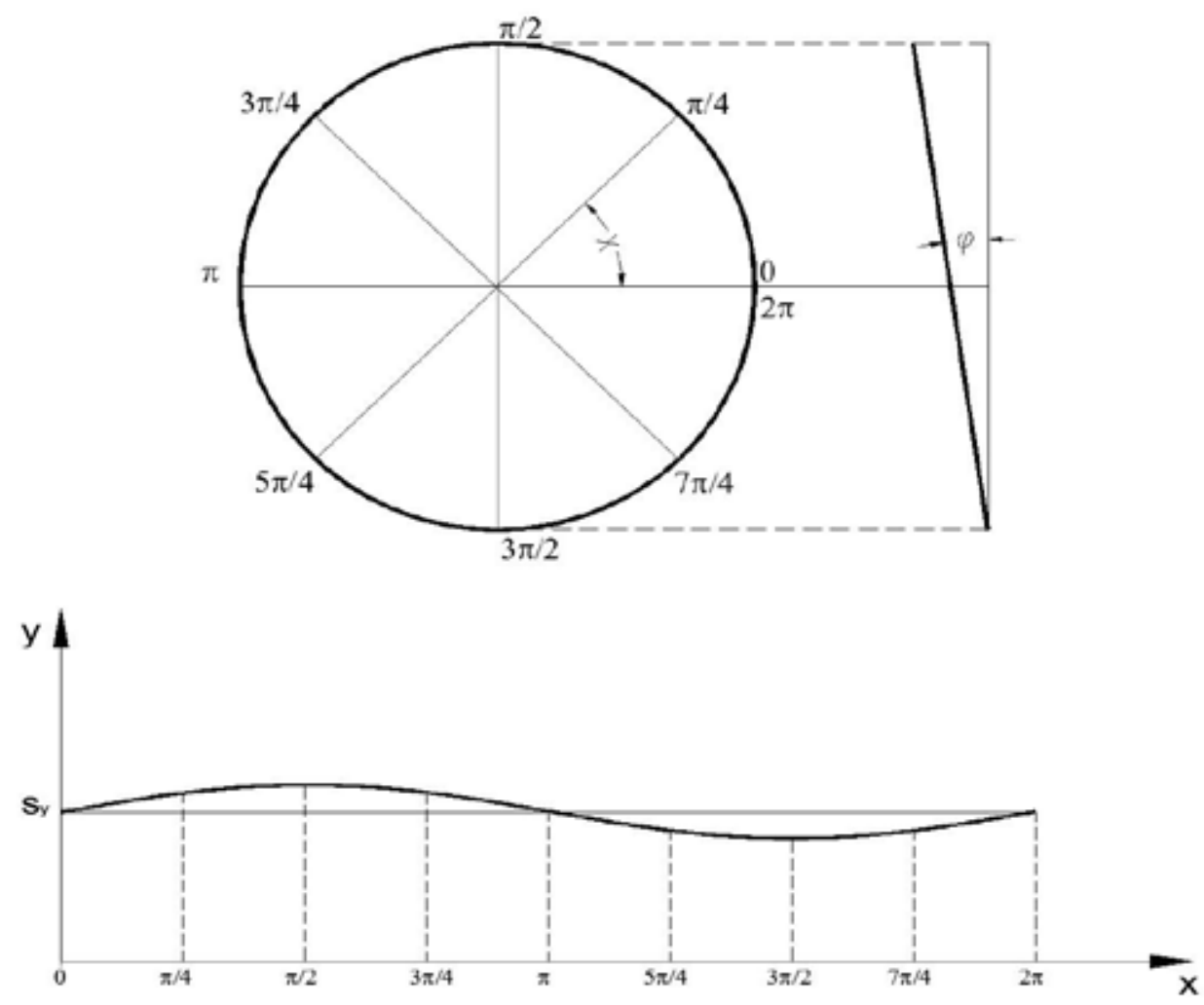

Izvor: obrada autora

Kako se niveleta na otvorenoj dionici ceste sastoji od pravaca i kružnih lukova, tako su i računalni programi (softveri) za projektiranje prometnica napravljeni tako da se isključivo pravci i kružni lukovi traže kao ulazni podatci za oblikovanje nivelete. Iz toga se lako da zaključiti da za određivanje visinskih elemenata kružnog kolnika ne možemo poslužiti izradom uzdužnog profila kroz os kružnog kolnika.

Postupak visinskog vođenja samog kružnog kolnika koji je pod nagibom počinje polaganjem pomoćne ravnine u kojoj leži vanjski rub kružnog kolnika. Kod tog postupka obavezno se mora 
koristiti računalni program s mogućnošću trodimenzionalnog crtanja. Kružnicom koja je položena horizontalno napravimo presjek na kosoj ravnini od koje smo napravili trodimenzionalni model. Dobivenom presječnom linijom definiran je vanjski rub kružnog kolnika te se iz nje putem programa mogu ekstrahirati koordinate točaka iskolčenja prema želji (npr. na svakih $5 \mathrm{~m}$ jedna točka sa $x, y, z$ koordinatama). Na osnovi vanjskog ruba kolnika, a putem širine kružnog kolnika i željenog poprečnog nagiba kolnika, visinski se odredi unutarnji rub kružnog kolnika.

Slika 9. Grafički postupak određivanja vanjskog ruba kružnog kolnika

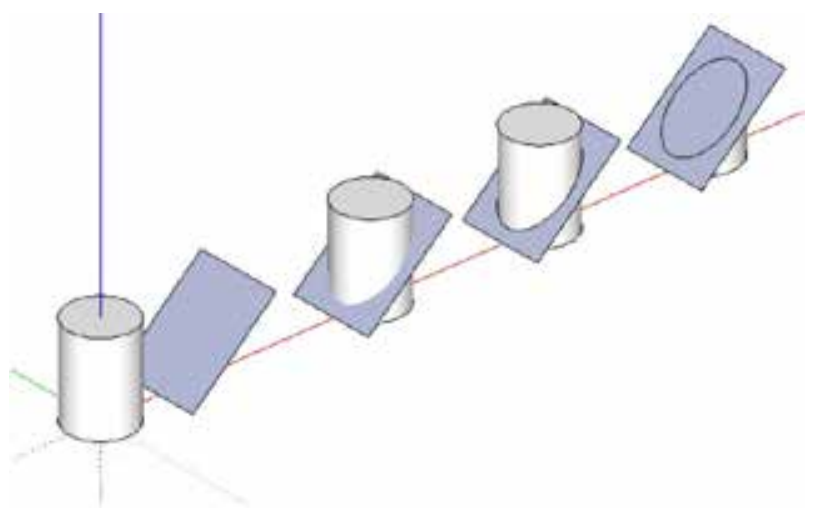

Izvor: https://forums.sketchup.com/t/is-sketchup-capable-of-drawing-an-elipse/16157/5

\subsubsection{Primjeri nivelacijskog plana kružnog kolnika}

Današnji računalni programi za trodimenzionalno crtanje $s$ mogućnošću modeliranja terena nude niz mogućnosti u prikazivanju željenih elemenata nacrta. Na slikama 10 i 11 dane su neke od mogućnosti grafičkih prikaza koji se odnose na visinsko vođenje kružnog raskrižja. Obrađen je primjer kružnog raskrižja s polumjerom vanjskog ruba $R v=9,5 \mathrm{~m}$ i nagibom ravnine $\mathrm{u}$ kojoj leži vanjski rub kružnog kolnika od $6 \mathrm{~cm}$ na duljini od $19 \mathrm{~m}$, što daje kut od $\phi=0,18^{\circ}$

Slika 10. Nivelacijski plan (situacija)

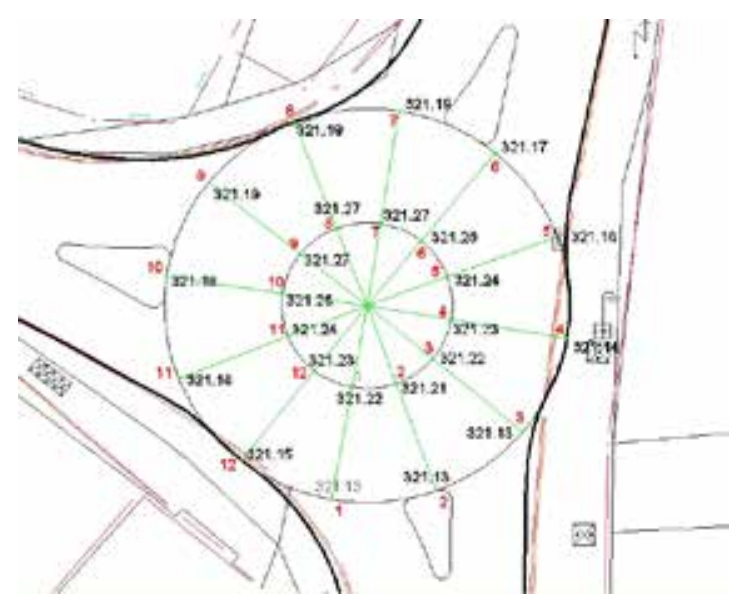

Izvor: obrada autora 
Slika 10 prikazuje nivelacijski plan (situaciju) s točkama iskolčenja vanjskog i unutarnjeg ruba koje su dane u parovima. Svakoj točki vanjskog ruba pridružena je po profilu točka unutarnjeg ruba na osnovi željenog poprečnog nagiba, pa tako postoji mogućnost ako je potreba prikazati i poprečni profil na nekom određenom mjestu.

Tablica 1. Primjer proračuna točaka iskolčenja vanjskog ruba kružnog kolnika

\begin{tabular}{|c|c|c|c|c|c|c|c|c|}
\hline \multirow[b]{2}{*}{$\begin{array}{l}\text { br. } \\
\text { točke }\end{array}$} & \multicolumn{3}{|c|}{ Podaci dobiveni modeliranjem plohe } & \multicolumn{5}{|c|}{$\begin{array}{c}\text { Podaci dobiveni putem formule za niveletu } \\
\text { vanjskog ruba kružnog kolnika }\end{array}$} \\
\hline & $x$ & $\mathrm{Y}$ & Z & Sy & Rv & kut X & $\operatorname{tg} \phi$ & $\begin{array}{c}\text { Sy }+ \\
\text { Rv sinx } \\
\operatorname{tg} \phi\end{array}$ \\
\hline 1 & 5518760,198 & 5012443,844 & 321,134 & 321,160 & 9,5 & $240^{\circ}$ & $0.06 / 19$ & 321,134 \\
\hline 2 & 5518765,121 & 5012444,278 & 321,130 & 321,160 & 9,5 & $\begin{array}{l}\text { dno } \\
270^{\circ}\end{array}$ & $0.06 / 19$ & 321,130 \\
\hline 3 & 5518769,159 & 5012447,123 & 321,134 & 321,160 & 9,5 & $300^{\circ}$ & $0.06 / 19$ & 321,134 \\
\hline 4 & 5518771,224 & 5012451,61 & 321,145 & 321,160 & 9,5 & $330^{\circ}$ & $0.06 / 19$ & 321,145 \\
\hline 5 & 5518770,758 & 5012456,529 & 321,160 & 321,160 & 9,5 & $\begin{array}{c}\text { centar } \\
0^{\circ}\end{array}$ & $0.06 / 19$ & 321,160 \\
\hline 6 & 5518767,88 & 5012460,546 & 321,174 & 321,160 & 9,5 & $30^{\circ}$ & $0.06 / 19$ & 321,175 \\
\hline 7 & 5518763,371 & 5012462,568 & 321,186 & 321,160 & 9,5 & $60^{\circ}$ & $0.06 / 19$ & 321,186 \\
\hline 8 & 5518758,458 & 5012462,053 & 321,190 & 321,160 & 9,5 & $\begin{array}{l}\text { vrh } \\
90^{\circ}\end{array}$ & $0.06 / 19$ & 321,190 \\
\hline 9 & 5518754,467 & 5012459,142 & 321,186 & 321,160 & 9,5 & $120^{\circ}$ & $0.06 / 19$ & 321,186 \\
\hline 10 & 5518752,475 & 5012454,62 & 321,175 & 321,160 & 9,5 & $150^{\circ}$ & $0.06 / 19$ & 321,175 \\
\hline 11 & 5518753,035 & 5012449,709 & 321,160 & 321,160 & 9,5 & $\begin{array}{c}\text { centar } \\
180^{\circ}\end{array}$ & $0.06 / 19$ & 321,160 \\
\hline 12 & 5518755,986 & 5012445,747 & 321,145 & 321,160 & 9,5 & $210^{\circ}$ & $0.06 / 19$ & 321,145 \\
\hline
\end{tabular}


Slika 11. Situacija sa smjerom tečenja vode

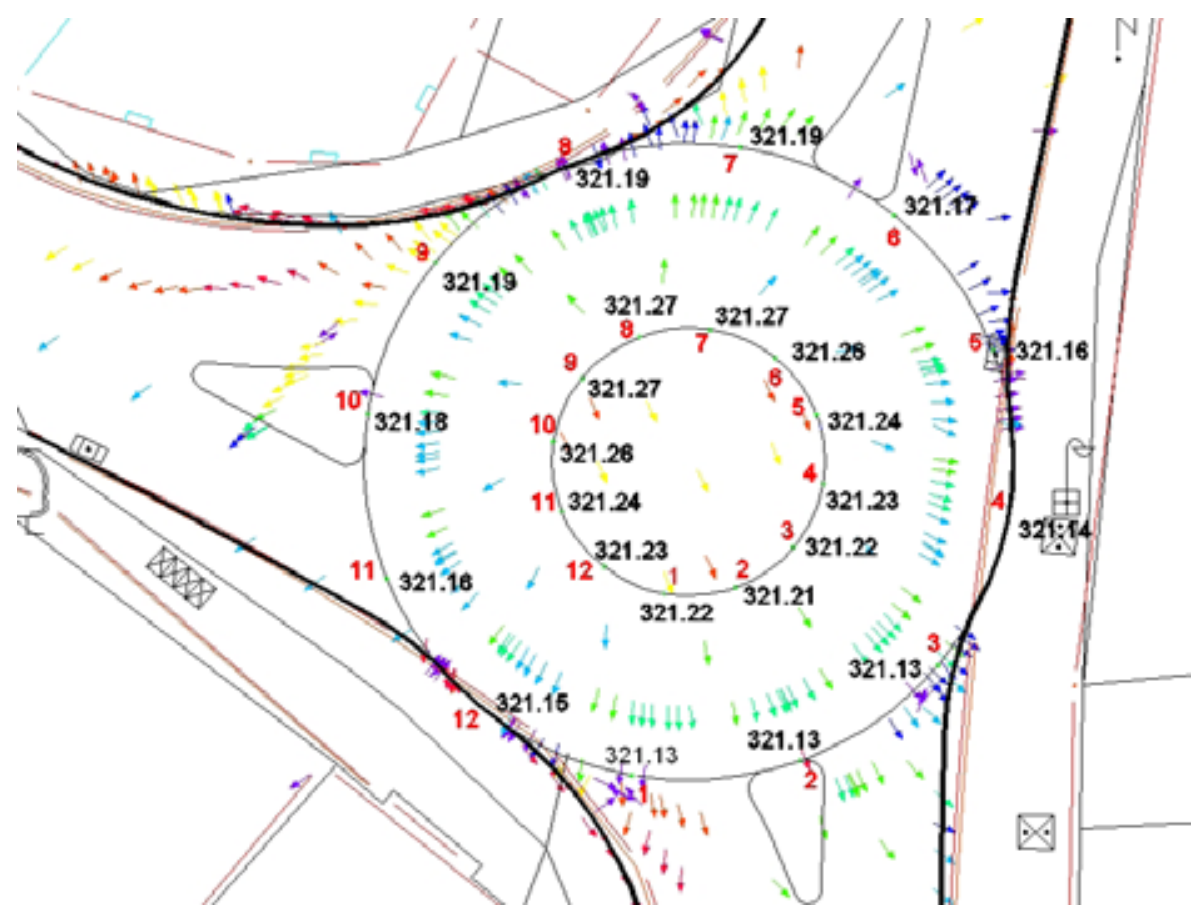

Izvor: obrada autora

Slka 11 prikazuje situaciju sa smjerom tečenja vode koja je vrlo korisna kod određivanja mjesta za postavljanje recipijenata za prihvaćanje oborinske vode kao što su slivnici i linijske rešetke. Već je istaknuto da u slučajevima gdje je ravnina u kojoj leži vanjski rub kružnog raskrižja veća od 2,5\% posebnu pozornost treba posvetiti odvodnji površinskih oborinskih voda, zato što tada poprečni nagib kružnog kolnika nije konstantan i istog predznaka, već u određenim dijelovima raskrižja dolazi do potpunog vitoperenja kružnog kolnika. U tim slučajevima ovaj nacrt trebalo bi napraviti ako se i ne priloži u projektnu dokumentaciju kao provjeru za postavljanje pozicije recipijenata.

\section{REGULATIVA VEZANA ZA VRSTU I SADRŽAJ PROJEKATA ZA JAVNE CESTE}

Današnja zakonska regulativa kroz Pravilnik o vrsti i sadržaju projekata za javne ceste (NN 53/02) propisuje sadržaj idejnog, glavnog i izvedbenog projekta za javne ceste, pa tako u predmetnom pravilniku stoji (stavke koji se odnose na građevinski projekt prometnih površina) da Idejni projekt za javnu cestu mora sadržavati sljedeće nacrte:

- situaciju javne ceste u mjerilu 1: 5000 ili većem s osi trase i stacionažama,

- uzdužne profile u mjerilu 1:5000/500 ili većem,

- normalni poprečni profil u mjerilu 1: 100 ili većem. 
Prema istom pravilniku Glavni projekt za javnu cestu mora obvezatno sadržavati odgovarajuće tlocrte, presjeke i poglede, a naročito:

- situaciju javne ceste u mjerilu 1 : 1000 ili većem na katastarskoj podlozi s ucrtanom granicom građevne parcele, ogradom, konturom građevine (nasipi i usjeci) s osi trase i stacionažama,

- uzdužne profile u mjerilu $1: 2000 / 200$,

- normalni poprečni profil u mjerilu 1:50 ili 1: 100,

- poprečni profili u mjerilu $1: 200$ ili većem.

Iz izdvojenih članaka vidljivo je da su kao nacrti koji se traže u smislu visinskog vođenja trase navedeni uzdužni profili i poprečni profili koji se izrađuju na osnovi definiranih uzdužnih profila. Pravilnik ne uzima u obzir specifičnosti projektiranja raskrižja već daje univerzalne zahtjeve koji vrijede za otvorene dionice ceste.

\section{ZAKLJUČAK}

Iz razloga sve veće primjene kružnih raskrižja kao rješenja za spoj različitih prometnih pravaca te višegodišnjeg nedostatka domaćih propisa i standarda za projektiranje kružnih raskrižja poduzeće „Hrvatske ceste d. o. o." je u srpnju 2014. izdalo „Smjernice za projektiranje kružnih raskrižja na državnim cestama“. No, pravilnik iz 2002. g. koji propisuje obavezan sadržaj projekata za javne ceste je zastario i neusklađen, te ne uzima u obzir specifičnosti projektiranja kružnih raskrižja, već daje univerzalne zahtjeve koje vrijede za otvorene dionice ceste.

Kako su čvorišta (raskrižja) glavne točke koje omogućuju funkcioniranje čitavoga prometnog sustava, tako je potrebno i kod načina rješavanja čvorišta svaki slučaj podrobno proučiti i posvetiti mu dovoljno pažnje jer je nepravilno konstruirano čvorište, osobito pri opterećenijim cestama, opasnost za sigurnost prometa.

Kroz analizu i usporedbu visinskog vođenja klasičnih raskrižja u jednoj razini i kružnih raskrižja prikazani su osnovni elementi visinskog vođenja za oba tipa raskrižja te koji su sve ulazni podatci potrebni računalnim programima (softverima) za projektiranje prometnica. Iz analize je vidljivo da se za određivanje visinskih elemenata kružnog kolnika ne možemo poslužiti istim postupkom visinskog vođenja koji imamo kod otvorene dionice ceste ili kod klasičnih raskrižja u razini, putem izrade uzdužnog profila kroz os kružnog kolnika. Potrebno je uvesti novi nacrt koji nije naveden u „Pravilniku o vrsti i sadržaju projekata za javne ceste“ (NN 53/02) a koji je logičniji i prilagođen samoj definiciji vođenja nivelete kružnog kolnika - nivelacijski plan kružnog raskrižja. Ovaj nacrt nije pogodan samo za primjenu kod kružnih raskrižja već se može koristiti i kod klasičnih raskrižja zbog detaljnosti točaka iskolčenja spojeva rubova kolnika (izljevno-uljevni polumjeri) glavne i sporedne prometnice.

Prikazana trigonometrijska funkcija $f(x)=S y+R v \sin x \operatorname{tg} \phi$ prema kojoj se izvodi i ponaša niveleta vanjskog ruba kolnika može poslužiti kao osnova za unaprjeđenje postojećih računalnih programa za projektiranje prometnica, kojom bi se omogućilo visinsko vođenje kružnog kolnika direktno računskim putem određivanjem same nivelete a ne grafički, posrednim putem preko ravnine u kojoj leži vanjski rub kružnog kolnika. Sam računski postupak puno je jednostavniji i brži od 
grafičkog, kod kojeg se traži presjek pomoćne ravnine u kojoj leži vanjski rub kružnog kolnika s valjkom promjera kružnog raskrižja, dok se kod računskog načina direktno putem jednostavne formule koja sadrži tri konstante i jednu varijablu izračuna onoliko točaka koliko je potrebno za preciznu izgradnju, što ovisi o vanjskom polumjeru kružnog raskrižja.

\section{LITERATURA}

Hrvatske norme, HRN U.C4.050

Korlaet, Ž. (1995) Uvod u projektiranje i građenje cesta, Zagreb: Građevinski fakultet Sveučilišta u Zagrebu

Legac, I. (2006) Cestovne prometnice I / javne ceste, Zagreb: Fakultet prometnih znanosti

Maletin, M. (2009) Planiranje i projektovanje saobraćajnica u gradovima, Beograd: Orion art

Pravilnik o vrsti i sadržaju projekata za javne ceste (NN 53/02)

Građevinski fakultet Sveučilišta u Rijeci (2014) Smjernice za projektiranje kružnih raskrižja na državnim cestama,

Zagreb, Hrvatske ceste d. o. o. 


\title{
GRADE LEVEL PLAN OF ROUNDABOUTS AS CONTENT OF PUBLIC ROAD PROJECTS ${ }^{4}$
}

\begin{abstract}
This paper provides an analysis and comparison of vertical alignment of classical intersections at one level and roundabouts and detects the problem of non-compliance with regulations that prescribes the required project content related to intersections. There are also some examples of roundabout drawings given as part of the content of public road projects. Until recently in Croatia, as a solution for a place of the intersection of traffic flows, classical intersections were dominantly applied at one level, and in that way the participants in the construction process had some requirements that are not applicable to roundabouts, both in the assignment of project tasks and for making technical drawings in order to process the altitude of roundabouts. Roundabouts have different geometry and, therefore, different inputs that are required for computer programs for road design than those for classical intersection design at a single level. The purpose of this article is to point out current issues and problems in roundabout design, while the aim of the paper is to recommend the content that the public road project must have in case of roundabout design.
\end{abstract}

Key words: roundabouts, grade level plan, grade line, vertical alignment

MEng in Civil Engineering, Teaching Assistant, Polytechnic of Rijeka, Vukovarska 58, 51000 Rijeka, Croatia.

E-mail: veljko.pevalek@veleri.hr

2 PhD, College Professor, Polytechnic of Rijeka, Vukovarska 58, 51000 Rijeka, Croatia. E-mail: ivica.barisic@veleri.hr

3 Professional Specialist in Transport Engineering, Teaching Assistant, Polytechnic of Rijeka, Vukovarska 58, 51000

Rijeka, Croatia. E-mail: damir.pilepic@veleri.hr

4 Received: 15 January 2018; Accepted: 1 March 2018 